\title{
The vineyards of Laconia
}

\author{
ANDREW DALBY \\ Saint-Coutant, France
}

\begin{abstract}
RESUMO: Uma demonstração do método pelo qual detalhes da história social da Grécia arcaica podem ser obtidos a partir de fragmentos da literatura perdida. Em um estudo de Alcman, fr. 92 Davies, o texto, os aromas de vinhos e as origens geográficas de vinhos são consideradas em seqüência. A gastronomia de Alcman é colocada no contexto de outras obras de Alcman e da cultura hedonística da antiga Esparta.
\end{abstract}

PALAVRAS-CHAVE: Alcman; vinho grego; vinhas; luxúria; Esparta; Lacônia.

'Water is best' (Pindar, Olympian 1.1). Wine was none the less an essential ingredient in Greek society from the earliest literature and the earliest history.

Yet we know all too little of the real nature and the real taste of Greek wine - at least until we come to Chian and Thasian and their various competitors, so popular, it seems from comedy, in fifth and fourth century Athens (Bowie, 1995; Dalby, 2000; Brock, 1994). There are, indeed, some famous older names. But where did Bibline come from (West, 1978, p.306)? What was Pramnian (E. Meyer, RE s.v. Pramnios)? Did Archilochus really taste the Ismarian that had been given to Odysseus (Archilochus fr. 2 West; Dalby, 1996, p. 99)? These are questions suitable for a long symposium.

Six, among the oldest of those older names for wines, come from a single scrap of seventh century ВС poetry. Its implications deserve exploring, for they exemplify, in a few lines of Greek, many of the difficulties and the rewards of the hunt for social history, for 'real life', in the fragments of archaic lyric.

Alcman, the choral poet of early Sparta, named six vintages from the Spartan hinterland in a passage of lyric verse which, in the early third century AD, Athenaeus was to quote in the Deipnosophists. Of this poem of Alcman's we now know only ragged remains that are preserved in the Byzantine Epitome of the Deipnosophists. Alcman's work is lost and the full text of books I and II of Athenaeus' gastronomic miscellany are also lost.

We may begin with a translation of the passage from the Epitome, a translation which will be justified in the following discussion:

Alcman somewhere describes as 'intrinsically warming [ápyron] and flower-scented' the wine that comes from Five Hills, a place seven [or sixty] stadia from Sparta; [? elsewhere he lists the wines or vineyards] of Denthiades, a fortress, of Oenunta [or rather Oenus], of Onogla and Stathmi: the latter are farms lying near Pitane. He says: 'Oinountias wine or Denthis or Karystios or Onoglis or Stathmitas,' [? including in his list] the wine of 
Carystus, a place near Arcadia. By ápyron he means 'not boiled': they did use boiled wines also. (Alcman fr. 92 Davies, 134 Calame; Epitome of Athenaeus $31 \mathrm{c}-\mathrm{d}$.

Since it is filtered through the Epitome it is not surprising that there are real problems with the text and its logic. It will be wisest to specify these problems (if not to solve them) before considering in turn what can be said of the tastes of Alcman's wines, of the vineyards from which they came, and of the literary context of the fragment.

\section{The text}

Editions of the Epitome are not easy to use (the best for books I and II is Desrousseaux, 1956), so it is necessary to set out in full the texts of the two significant manuscripts. C, the Paris manuscript, gives more:

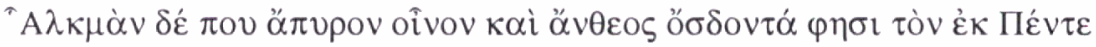

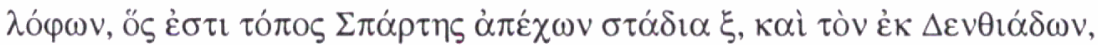

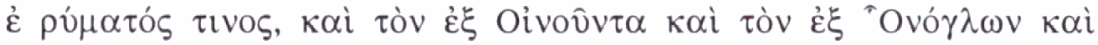

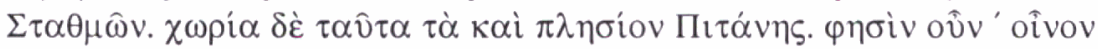

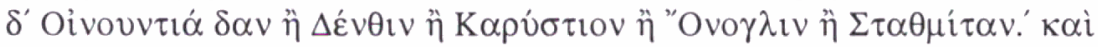

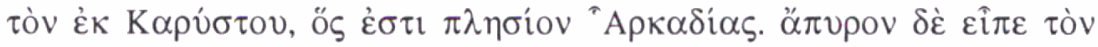

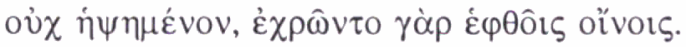

The words tà kai are variously emended, most convincingly in Page's keitai. Manuscript E (Florence) is, as often, more laconic:

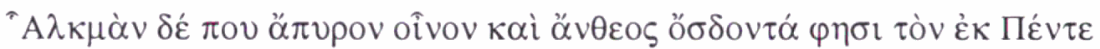

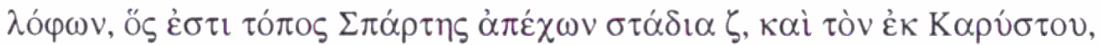

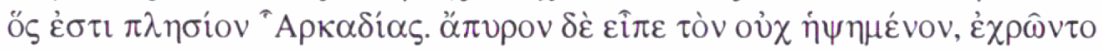

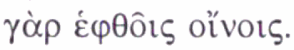

Several scholars - Bergk, Wilamowitz and Edmonds, among others - have tried to construct a connected passage of lyric poetry, attributable to Alcman, from this material. Their attempts are set out in full in Calame's apparatus criticus, for those who want to look. But the problem with any such attempt is that the Epitomator had a brusque way with quoted verse. The mission of all abbreviators is to cut the verbiage. In: Athenaeus's verse quotations (as can be seen when comparing the surviving books III to XV of the Deipnosophists with the Epitome of those books) there is much that is fascinating but failed to fascinate the Epitomator. Thus, although we do not know how drastically the text of Alcman and its context were cut away before they reached us, we must be prepared for the worst.

The three scholars just named all made the assumption that - as the Epitomator's first sentence literally says - Alcman called the wine of all six of these places ápyron kai ántheos ósdonta. Knowing Athenaeus' magpie habits, knowing also what happens when texts are abridged, we must question whether this was really so. It is at least as likely that in one passage Alcman described the Five Hills wine thus, and that in another passage he mentioned the other five vintages without applying any such description to them. A third 
possibility is that the Five Hills were not, as the Epitomator says, 'a place', but were the five places about to be listed. Against that, as we shall see below, these places were not all equally near Sparta and do not seem to belong in any such collective designation.

As a specimen of the illogicalities of the Epitome we may consider in the Paris text the strange position of the clause about Carystus, kaì tòn ... Arkadias. It logically belongs before the quoted list, not after it. The magisterial Porson, indeed (see Calame, 1983, ad loc.) wanted to move this clause to make it follow erymatós tinos. But such problems call for explanation, not concealment. This particular problem is to be explained by the probability that Athenaeus had said something longer about Carystus at this point, perhaps giving it a whole sentence, perhaps distinguishing it from Carystus in Euboea.

\section{The tastes}

We begin with ápyron, the word that I propose to translate 'intrinsically warming': a clumsy phrase, I admit. The last sentence of the passage quoted above gives a very different explanation of the word. According to this, ápyron means 'not boiled'. Most readers of the Epitome have probably dismissed this as insensitive nonsense, and nonsense is probably what it is, although the writer's justification for it, 'they did use boiled wines also,' is triumphantly borne out by a fairly early source. The agricultural work of pseudo-Democritus, surviving in excerpts in the Byzantine collection Geoponica, asserts that 'the Spartans boil their wine until it is reduced by a fifth, and use it after four years' (Geoponica 7.4). The practice helped the stabilisation of wine for long distance trade (Diophanes in Geoponica 7.17) and is recorded for medieval Malmsey (Lambert-Gócs, 1990, p. 76). It is still used as a step in the manufacture of some sweet wines, though fortification with spirits is now more popular.

In: spite of all this ápyron is perhaps unlikely to be a technical term in winemaking here. The 'unfermented' of Liddell and Scott (1925-40, s.v. ápyros), accepted by Calame (1983, p. 284), is even less convincing than the gloss 'not boiled' in the Epitome. 'Unfermented wine' is a contradiction in terms in Greek, as it would be in most languages (before fermentation the substance is not properly called oinos 'wine'; it is called gleukos 'must', and again Liddell and Scott 1925-40 is seriously imprecise with its rendering 'sweet new wine' for glêukos). Moreover, neither of these proposed meanings - 'unfermented', 'not boiled' - is paralleled in other recorded uses of the word ápyros. The commonest meaning elsewhere is 'not yet subjected to fire', as in another Alcman fragment (17 Davies, 9 Calame). But there are also Pindar's hierà ápyra (Olympian 7.48), 'sacrifices not calling for fire', and Aeschylus's árdis ápyros (Prometheus 880), the gadfly sting 'whose heat does not come from fire'. This, I believe, is the closest to Alcman's meaning here: wine is ápyros because it is intrinsically warming, with a heat that is independent of fire.

Alcman's phrase ántheos ósdonta, which I translate 'flower-scented', is just as hard to pin down. Literally it means what I say. But it could refere to the ánthos oinou (Galen v.2, p.628 Kühn), the 'flower of wine', analogously known as flor in Latin, Spanish and Portuguese, a microbial surface layer that forms during the maturing of certain wines, especially sherry-like wines: if so it would be criticism rather than praise, for wine should not taste or smell of flor, and it need not do so. The cure is prescribed in Geoponica 7.25. A rather more likely explanation is offered by the Byzantine scholar Eustathius in one of the many digressions, often based on study of Athenaeus, that occur in his Commentary on Homer (1449.12). 
Antheos ósdonta, Eustathius says, may be a periphrasis for the technical term anthosmias. Eustathius reverts to the topic at 1633.3-51 and makes the further link with the phrase ántheos osdómenos used of wine by the elegiac poet Xenophanes (fr. 1 West).

The Epitome seems to confirm that Athenaeus had previously thought what Eustathius says. Although there is an intervening irrelevant passage, the quotation from Alcman is eventually followed in the Epitome, at 31f-32a, by this: 'On the making of anthosmías wine Phaenias of Eresus says as follows: "One part seawater is added to fifty parts must: anthosmias is the result." After two further recipes, the Epitome proceeds to give a list of wines that included seawater: Myndian, Halicarnassian, Rhodian and the wellknown and widely falsified Coan (32 d-e; cf. Cato, On Farming 112-3). The concatenation is surely not accidental. We can see, behind the inconsequentiality of the Epitome, that Athenaeus was now taking up with additional references the topic he had previously raised by quoting the words ántheos ósdonta from Alcman, and he was linking to Alcman's words the later technical term anthosmias.

The question over 'flower-scented' is thus the same as that over 'intrinsically warming': is Alcman describing an aroma in his own words or is he using a technical term? We remain uncertain. Anthosmías was well enough known later. Aristophanes, Frogs 1150, Plutus 807, tells us that it was red wine; Xenophon, Hellenica 6.2.6 shows us that it was the soldiers' favourite out of what was available on Corcyra. Commentators on these passages have generally been unaware of the technical meaning of the term, which is not noticed by Liddell and Scott (1925-40 s.v. anthosmías). But Alcman is writing much earlier, possibly before the technical term had been invented; 'flower-scented' is a fine way to describe some muscat and Malmsey wines, among others; and there is no other evidence that brine was added to must by any other Laconian producer.

\section{The vineyards}

As a preface to the geographical discussion let us note that Strabo, writing in the first century $\mathrm{AD}$, confirms independently that 'Alcman spoke of Carystian wine' (10.1.6/ 336), and Stephanus of Byzantium cites Strabo on this detail (Ethnica s.v. Karystos). Hesychius' Lexicon gives Déntheis, Karystios, Óniglis as names of wines (the first said to be Laconian), and Oinoúsios as a grape variety. Surely Alcman is the ultimate source for Hesychius too. What, then, can we know of the six wines of Alcman's Laconia?

Pitane was one of the constituent villages of Sparta (F. Bölte, RE s.v. Pitana, and see now Alcman fr. 11 Davies). Five Hills, Onogla and Stathmi are otherwise unknown, but, on the basis of information in the text, they were in the immediate vicinity of the city. Five is a popular number for geographical features, according to modern survey maps of the Peloponnese - even Taygetus has been called 'Five Fingers' - and it seems fruitless to try to find the five hills. Calame's suggestion (1983, ad loc.) that the five hills of Sparta itself are meant cannot be accepted unless one is prepared to ignore the Epitomator's statement that Five Hills was seven (or sixty) stadia from the city.

Oenus as a locality is also therwise unknown except from Stephanus of Byzantium's geographical dictionary. 'Oenus,' he says, 'is a small town of Laconice: so Androtion and Didymus. Adjectives Oinoúntios and Oinountiás.' It is Stephanus's entry that justifies the substitution of Oinoûntos for Oinoûnta in printed texts of the Epitome. Now there was also a river Oenus (e.g. Livy 34.28.1), identified with the modern river Kelefina which flows 
into the Eurotas from the east two miles north of Sparta. The town and the well-named vineyards of Oenus may, then, have overlooked the river Kelefina and, if so, were also not far from Sparta.

Sadly, I cannot show a link between any of these places and the modern village that Miles Lambert-Gócs calls Stafilakia, and survey maps call Gramousa, twenty miles southeast of Sparta, 'the sort of place Peloponnesians ... do not bother telling anyone about, but visit as need be to fill up demi-johns. The villagers of Stafilakia boast of growing over twenty grape varieties, and of having nearly as many sorts of wine' (Lambert-Gócs, 1990, p. 193).

Carystus and Denthiades can be roughly located: both were disputed territory on the borders of Laconia. À propos of the Alcman passage, Strabo describes Carystus as 'a place belonging to Aegys, towards Arcadia,' though it is not in Pausanias' list (8.27.4) of the villages of Aegytis that contributed to the population of Megalopolis. Aegys was not far from modern Leontari, recently prolific in wine (Baedeker, 1894, p. 287). Carystus itself is traditionally identified with the hill Paleokastro at Yoryitsianika Kalivia (Frazer, 1898, on Pausanias 3.21.2; Loring, 1895, p. 45-6).

Alcman's Denthiades is usually assumed to share its name and its location with the Ager Dentheleatis of Tacitus, Annals 4.43, and with the city called Denthalii (a name variously spelt in the manuscripts) which Stephanus of Byzantium describes as "one of the cities disputed between the Messenians and Lacedaemonians' (Ethnica, s.v. Denthalioi). The Ager Dentheleatis was the central section of the western foothills of Taygetus, stretching from the watershed as far west as modern Kalamata. It is part of Messenia according to maps, but historically Messenian and Laconian by turns (Frazer, 1898, on Pausanias 4.31.1).

Now certain districts of the southern Peloponnese have been praised for their wine. Although most of the sweet and dry Malmsey exported from medieval Monemvasia had come from the Aegean islands and Crete, there are also said to have been vineyards on the mainland near Monemvasia, now long abandoned (Lambert-Gócs, 1990, p. 74-8; Baedeker, 1894, p. 262). Equally important, one of the seven towns offered by Agamemnon to Achilles in the Iliad $(9.152,294)$ was 'vinous Pedasus', identified by Strabo (8.4.3) and Pausanias (4.35.1), for reasons they do not give, with Methone in Messenia. Later known as Modon, this was one of the four medieval entrepôts of the Morea, the others being Patras, Monemvasia and Nauplia. The Iliad, with its formulaic adjective, suggests that it had a trade in wine long before the other three, and we may think that Pausanias (4.35.6) goes some way to confirm it, though his anecdote of Illyrian kidnappers does not depend on Methone's being a regular port of call or exporter of wine.

The only other reference to southern Peloponnesian wine that can be linked with Alcman's vineyards, even in the most hypothetical way, is that of Theognis 879-884: 'Drink the wine supplied to me by vines of the hills under Taygetus, grown in the mountain valleys by old Theotimus, dear to the gods, who brought cold water to them from Platanistus: drinking this, you will scatter hard cares; armed with this, you will be much the lighter.' Who wrote this little drinking refrain: some poetic Spartiate (as Bölte guessed in his $R E$ article 'Taygetos')? This is one of the verses usually thought not to be by the real Theognis of Megara, at all events. There is no knowing if Theotimus 'god-honoured' and Platanistus 'the plane trees' were real (there are many plane trees and many places similarly named) but we may, if we please, pencil in this pseudo-Theognidean vineyard somewhere in the deep valleys of the Ager Dentheleatis. 


\section{The cultural context}

The Alcman passage, exiguous as it is, has a real importance. It reminds us of the breadth, the variety, the local roots, of the luxury culture of archaic Greece. Sparta was a place of song (Pindar fr. 199 Snell, 189 Bowra), of gardens (Ibycus fr. S151 Davies = P. Oxy. 2735) and of vineyards. In: wine, as in food (Herodotus 6.60) early Sparta offered a warm welcome to travellers (compare Theognis 783-8, not to mention Odyssey book 4). Spartans drank wine with, as well as after, their meals (Dicaearchus quoted by Athenaeus $141 \mathrm{~b}$ ) and were not averse to good, and strong, wine. 'The Spartans say that Cleomenes [I] the Spartiate went mad because he associated with Scyths and learnt to drink wine neat. So whenever they want to drink wine relatively unmixed, they say "Scythise it!" (Chamaeleon of Heraclea fr. 31 Koepke, quoted by Athenaeus 427b: compare Herodotus 6.84; Griffiths, 1989). Drunkenness was perhaps encouraged in Helots (Plutarch, Lycurgus 28; David, 1989), but it was not their exclusive privilege.

Among these Spartans (see Stibbe, 1996), Alcman was not out of place. His work is hard for us to come to terms with. His language was difficult even for later Greeks; thus, although he was edited, annotated and read, he was not read widely. The resulting sparsity of Alcman fragments in the papyri, as compared, say, with those of Sappho and Alcaeus, means that there are only a couple of long passages of Alcman, along with many very short ones, that we can now read. But every reader can recall Alcman fragments that pass the Housman test of poetry ('my skin bristles': Housman, 1933). In: a remarkable way he married powerful poetry with humorous self-reference. This was self-reference in the third person, for he wrote to be sung by choruses, not to be recited by a single voice. From fragment 17 , already cited, comes the promise of a cauldron "not yet subjected to fire, but soon to be full of pea soup, such as omnivorous Alcman likes hot after the [winter] solstice. He eats no fancy concoctions, but looks for common stuff, like the people.' With the dizzying shifts of subject and focus that appear to have been his speciality (Calame, 1981) we have for the present no idea in what context Alcman named these vineyards and assessed their wines.

Later Spartans wrote little, and to most outsiders of the fifth and fourth centuries Sparta seemed to glory in the discomforts of life. "No wonder the Spartans are the bravest of all: any right-thinking person would rather die ten thousand times than take a helping of such poor food,' said the proverbial Sybarite (Athenaeus 138d). Later, too, the earnest king Cleomenes III (late third century BC), though he served slightly better than the usual wine when non-Spartans were present, served it in grudging quantities. Cleomenes was supposed to be reacting against a slippage of Spartan morality under Areus and Acrotatus, when 'select wines' and other heady luxuries were served to Spartans (all this is from Phylarchus quoted by Athenaeus 142e). Moralists are, of course, not to be relied on concerning the goodness of the good old days and the newness of moral decline: who knows if Phylarchus had the story right?

To set against all these stereotypes one would like to trace some continuation of a Spartan tradition of wine appreciation ... Well, perhaps we can. What of the sweet Malmsey, speciality of Laconia and wealth of Monemvasia throughout medieval times, whose manufacture spread westwards, in the nick of time, from Greece by way of the western Mediterranean to Madeira? 


\section{Bibliography}

BAEDEKER, K. Greece. Leipzig: Baedeker, 1894.

BOWIE, E. L. Wine in Old Comedy. In: MURRAY, O. \& TECUSAN, M. (Ed.). In: Vino veritas. London: British School at Rome, 1995, p. 113-125.

BROCK, R. “Ancient Greece”. In: ROBINSON, J. (Ed.). The Oxford companion to wine. Oxford: Oxford University Press, 1994, p. 464-8.

CALAME, C. Le navire de Dionysos: un témoignage d'Alcman? Etudes de lettres, ser. 4, v. 4, n. 2, p.15-24, 1981.

CALAME, C. (Ed.). Alcman. Roma: Edizioni dell'Ateneo, 1983.

DALBY, A. Siren feasts: a history of food and gastronomy in Greece. London: Routledge, 1996.

DALBY, A. Topikos oinos. In: HARVEY, D. \& WILKINS, J. (Ed.). The rivals of Aristophanes. London: Duckworth, 2000, p. 397-405.

DAVID, E. Laughter in Spartan society. In: POWELL, A. (Ed.). Classical Sparta: techniques behind her success. London: Routledge, 1989, p. 1-25.

DESROUSSEAUX, A. M. (Ed.). Athénée de Naucratis, Les deipnosophistes, Livres I et II. Paris: Les Belles Lettres, 1956.

FRAZER, J. G. (Ed.). Pausanias's Description of Greece. London: Macmillan, 1898.

GRIFFITHS, A. Was Kleomenes mad? In: POWELL, A. (Ed.). Classical Sparta: techniques behind her success. London: Routledge, 1989, p. 51-78.

HOUSMAN, A. E. The name and nature of poetry. Cambridge: Cambridge University Press, 1933.

LAMBERT-GÓCS, M. The wines of Greece. London: Faber, 1990.

LIDDELL, H. G. \& SCOTT, R. A Greek-English lexicon. 9th ed. by H. S. Jones and R. McKenzie. Oxford: Clarendon Press, 1925-40.

LORING, W. Some ancient routes in the Peloponnese. Journal of Hellenic studies, v.15, p. $25-89,1895$.

STIBBE, C. M. Das andere Sparta. Mainz: Philipp von Zabern, 1996.

WEST, M. L. Hesiod: Works and days. Oxford: Clarendon Press, 1978.

DALBY, Andrew. The vineyards of Laconia. Classica, São Paulo, 11/12, p. 281-288,1998/ 1999.

ABSTRACT: A demonstration of the methods by which details of the social history of archaic Greece may be extracted from fragments of its lost literature. In: a study of Alcman fr. 92 Davies, the text, the aromas of wines, and the 
geographical origins of wines are considered in turn. The gastronomy of Alcman is then placed in the context of Alcman's other work and of the hedonistic culture of early Sparta.

KEY-WORDS: Alcman; Greek wine; Vineyards; Luxury; Sparta; Laconia 